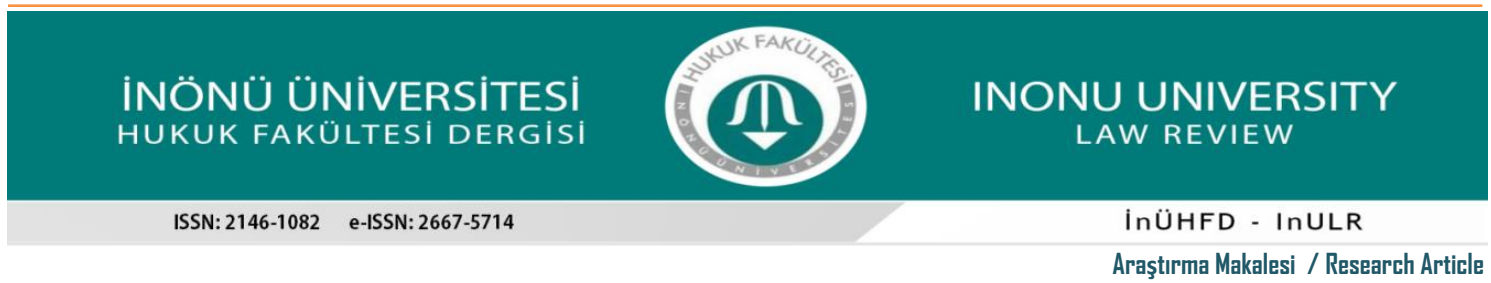

\title{
UNPACKING TEMPORARY PROTECTION OF REFUGEES: FAILURE OF DURABLE SOLUTIONS AND UNCERTAINTIES
}

\author{
MÜLTECILERIN GEÇICİ KORUNMASI: \\ KALICI ÇÖZÜMLERİN BAŞARISIZLIĞI VE BELİRSIZZLIKLER
}

İrem ŞENGÜL* $\stackrel{m}{*}$

\begin{tabular}{l} 
Makale Bilgi \\
\hline Gönderi: 07/09/2021 \\
Kabul : 07/01/2022 \\
Anahtar Kelimeler \\
\hline Geçici Koruma, \\
Kalıcı Çözümler, \\
Mülteci Hukuku, \\
Belirsizlik.
\end{tabular}

Article Info

Received: 07/09/2021

Accepted: 07/01/2022

\section{Keywords}

Temporary,

Protection,

Durable Solutions,

Refugee Law,

Uncertainty.

\begin{abstract}
Özet
$10.21492 /$ inuhfd.992439 do

Geçici koruma 1970lerden bu yana farklı bölgelerde (Güneydoğu Asya, Avrupa, Ortadoğu) geniş ölçekli mülteci hareketlerine pratik bir müdahale olarak tartış1lmış, teşvik edilmiş ve uygulanmıştır. Yine de, bu yaygın uygulama alanına rağmen geçici korumadan ne kastedildiği açık değildir ve politik ve akademik çevrelerde sıklıkla tartışılmaktadır. Geçici korumanın standartlaştırılması ve geliştirilmesi yönündeki çabalar geçici koruma alanındaki çalışmalara yön vermektedir. Bu makale, yalnızca geçici koruma nedir veya nasıl olmalıdır sorularına cevap aramak yerine, göz ardı edilen bir soruya odaklanarak literatüre katkı sağlamaktadır: Uluslararası mülteci rejiminde geçici koruma kategorisi nasıl ve neden ortaya çıkmışır ve ne gibi sonuçları olmuştur? Geçici koruma üzerine yayınlanmış politika kılavuzları, yumuşak hukuk araçları ve literatürdeki araştırmalar incelenerek geçici korumanın tepeden inme bir şekilde devlet çıkarlarını önceleyerek ortaya çıktığı gösterilmektedir. Geçici korumanın gelişimini ve sonuçlarını açarken uluslararası mülteci rejimindeki geleneksel kalıcı çözümlerin başarısızlığı ve geçici korumanın içkin belirsizlikleri arasındaki ilişki temel alınmıştır. Sonuç olarak, bu çalışma geleneksel kalıcı çözümlerin başarısızlığı bağlamında geçici korumanın devlet çıkarları doğrultusunda bir mülteci yönetim aracı olarak belirsizlikler yarattığını ve bu belirsizlikleri devam ettirdiğini ortaya koymaktadır.
\end{abstract}

\begin{abstract}
Temporary protection has been discussed, promoted, and implemented in different regions (Southeast Asia, Europe, Middle East) since 1970s as a practical response for large-scale refugee movements. Nevertheless, despite its wide usage and implementation, what is meant by temporary protection is not clear, and frequently debated in policy and academic circles. The attempts to standardize/improve temporary protection frameworks dominate the studies on temporary protection. Rather than solely focusing on what is temporary protection or what it should be, this article makes a novel contribution to the literature by asking a neglected question: how and why has the category of temporary protection been developed in the contemporary international refugee regime and with what consequences? By focusing on the policy guidelines, soft-law instruments, and existing literature on temporary protection, it shows that temporary protection has been developed in a topdown manner focusing solely on the state interests. The failure of durable solutions framework in international refugee regime and inherent uncertainties of temporary protection are intrinsically related to each other and their relation is taken as key to unpack the development and consequences of temporary protection regimes. This article concludes that temporary protection both creates and maintains uncertainty as a refugee management strategy which speaks to state interests in the context of the failure traditional durable solutions framework.
\end{abstract}




\section{INTRODUCTION}

Protection is arguably the main objective of international refugee policies. Although "everyone's talking about it, everyone is "doing" it", ${ }^{1}$ what is meant by protection varies among different contexts and different actors. In international refugee law, the main sources of protection are the Convention Relating to the Status of Refugees of 1951 (Refugee Convention) and the Protocol Relating to the Status of Refugees of 1967 (Refugee Protocol). However, they do not provide a definition of protection in the texts. We also refer to international human rights law, humanitarian law, and other sources of international refugee law in tackling this question, yet none precisely clarify the meaning of the term. The proliferation of protection discourses in the forms of "temporary protection", "subsidiary protection", "complementary protection", "humanitarian protection" and so forth further complicates the task of defining protection. ${ }^{2}$

This article focuses on a particular form of protection, namely temporary protection, which has been formulated as a suitable protection response to large-scale refugee movements. The conceptualization of temporary protection dates back to the end of the 1970s, when the first mention of the terms "temporary asylum" 3 and "temporary refuge" 4 appeared in official documents. Since then, the international community has discussed the concept several times, while the United Nations High Commissioner for Refugees (UNHCR) played a significant role in its promotion by publishing soft-law instruments such as Executive Committee Conclusions. The temporary protection framework has been formulated as a practical response, providing lesser standards of protection than the Refugee Convention/Protocol to large numbers of refugees temporarily awaiting realization of durable solutions, without recourse to individual refugee status determination (RSD). ${ }^{5}$

Since 1970s, temporary protection has been implemented in various refugee situations and different regions such as Southeast Asia, Europe, and the Middle East. However, despite its wide usage and implementation, what is meant by temporary protection is not clear, and frequently debated in policy and academic circles. Neither policy frameworks nor doctrinal studies could provide an internationally accepted definition of temporary protection. ${ }^{6}$ Hence, most literature on temporary protection focuses on the improvement and standardization of temporary protection regarding its definition, beneficiaries, and content. In this regard, the possible legal basis of temporary protection in international refugee law, its relationship with the Refugee Convention/Protocol, its standards of protection, and the standards for its termination have been heavily debated within academic and policy circles with an attempt to improve them. ${ }^{7}$

Rather than solely focusing on what is temporary protection or what it should be, this article makes a novel contribution to the literature by asking a more fruitful question: how and why has the category of temporary protection been developed in the contemporary international refugee regime and with what consequences? It is argued that, in order to address this question appropriately, temporary protection should be contextualized within the broader context of contemporary refugee regime and its failures. The failure of durable solutions framework in international refugee regime and the related uncertainties of temporary protection are taken as key aspects to unpack the development and consequences of temporary protection frameworks.

\footnotetext{
${ }^{1}$ FERRIS, Elizabeth G.: The Politics of Protection: The Limits of Humanitarian Action, Brookings Institution Press, Washington, D.C. 2011, p.xii.

2 STEVENS, Dallal: "What Do We Mean by Protection?", International Journal of Minority and Group Rights, 20(1), 2013, p.234.

${ }^{3}$ UNHCR: "Executive Committee Conclusion No 5: Asylum”, 1977.

${ }^{4}$ UNHCR: "Executive Committee Conclusion No 15: Refugees Without an Asylum Country", 1979.

${ }^{5}$ UNHCR: "Note on International Protection”, UN Doc A/AC.96/830, 1994, para.45.

${ }^{6}$ UNHCR: "Roundtable on Temporary Protection: Summary Conclusions on Temporary Protection", 2012, para.1.

${ }^{7}$ For some prominent examples: COLES, G.J.L.: "Temporary Refuge and the Large Scale Influx of Refugees", Australian Year Book of International Law, 8, 1978-1980; HARTMAN, Joan F./PERLUSS, Deborah: "Temporary Refuge: Emergence of a Customary Law", Virginia Journal of International Law, 26(3), 1986; KJAERUM, Morten: "Opinion: Temporary Protection in Europe in the 1990s", International Journal of Refugee Law, 6(3), 1994; GIBNEY, Matthew J.: "Between Control and Humanitarianism: Temporary Protection in Contemporary Europe", Georgetown Immigration Law Journal, 14(3), 2000; HATHAWAY, James C./NEVE R. Alexander: "Making International Refugee Law Relevant Again: A Proposal for Collectivized and Solution-Oriented Protection". Harvard Human Rights Journal, 10, 1997; FITZPATRICK, Joan: “Temporary Protection of Refugees: Elements of a Formalized Regime", American Journal of International Law, 94(2), 2000; EDWARDS, Alice: “Temporary Protection, Derogation and the 1951 Refugee Convention". Melbourne Journal of International Law, 13(2), 2012; DURIEUX, Jean-François: "Temporary Protection: Hovering at the Edges of Refugee Law" in Ambrus, Monika/Wessel, Ramses A. (ed.), Netherlands Yearbook of International Law 2014: Between Pragmatism and Predictability: Temporariness in International Law, Asser Press, The Hague 2015; INELI-CIGER, Meltem: Temporary Protection in Law and Practice, Brill Nijhoff, Leiden 2018.
} 
Through the examination of policy guidelines, soft-law instruments, and existing literature, this article first examines the place of large-scale refugee movements in international refugee protection regime to reveal how temporary protection has been labelled as a practical tool to respond large-scale refugee movements. Second, it reveals the intrinsic relationship between the durable solutions framework in international refugee law and the development of temporary protection regime. Following the analysis of the attempts of standardizing/improving temporary protection frameworks in academic and policy circles, last section focuses on the inherent uncertainties of temporary protection regimes that lead to temporary protection's failure as an effective protection tool.

\section{TEMPORARY PROTECTION AS A RESPONSE TO LARGE-SCALE REFUGEE MOVEMENTS}

Temporary protection has developed as an emergency response to large-scale refugee movements. That is why, in unpacking temporary protection, we need first to contextualize largescale refugee movements in the international refugee regime. In other words, we need to explore why mass displacements led to development of a special form of protection response. Large-scale displacements arguably challenge the international legal regime of refugee protection in several ways. The international refugee law-which is mainly shaped by key international instruments of Refugee Convention and Refugee Protocol-works on providing protection to refugees on an individual basis. In the Refugee Convention/Protocol, the term "refugee" is defined as a person who:

"owing to well-founded fear of being persecuted for reasons of race, religion, nationality, membership of a particular social group or political opinion, is outside the country of his nationality and is unable or, owing to such fear, is unwilling to avail himself of the protection of that country..." 8

The Refugee Convention/Protocol provides important safeguards for refugees, such as protection against being sent back to a place where they would face threats to life or freedomknown as the norm of non-refoulement ${ }^{9}$ - and lists the rights and responsibilities of both state parties and refugees. In this system, especially the economic and social rights serve a "dual purpose"- that is, providing "a life of minimal dignity" during the exile, and facilitating the ties between refugee and the host country to ease a refugee's future naturalization. ${ }^{10}$ Hathaway describes the protection of Refugee Convention/Protocol as an "assimilative path" to naturalization, by an "expanding array of rights" as time passes. ${ }^{11}$

The Refugee Convention/Protocol's applicability during large-scale refugee movements and the possibility of derogation from the Refugee Convention has been questioned heavily, yet, it is still not clear today. ${ }^{12}$ Moreover, despite the fairly wide ratification of the Refugee Convention/Protocol, the legal principles and standards of response to large-scale refugee movements have been a concern in some regions - such as Southeast Asia and the Middle Eastwhere most of the states are not party to the Refugee Convention/Protocol or are party to the Refugee Convention/Protocol but have weak implementation. ${ }^{13}$

Although "mass influx" or large-scale movements are frequently referred to in the discourse of international refugee regime, they are not terms of art. In its general meaning, a "mass influx" characterizes the "sudden and rapid crossing of international borders by large numbers of uninvited foreigners" who escape persecution, danger, or threats to their lives. ${ }^{14}$ However, the term is not defined in the Refugee Convention/Protocol, or in any other universally binding human rights instrument. Considering the UNHCR's approach and relevant literature, Ineli-Ciger brings together

\footnotetext{
${ }^{8}$ Convention Relating to the Status of Refugees (adopted 28.07.1951, entered into force 22.04.1954) 189 UNTS 137 (Refugee Convention), Article 1(A)(2).

${ }^{9}$ Refugee Convention, Article 33.

${ }^{10}$ FITZPATRICK: "Revitalizing the 1951 Refugee Convention", Harvard Human Rights Journal, 9,1996, p.250. The Refugee Convention's Article 34 mentions naturalization as a pathway for termination of refugee status: "The Contracting States shall as far as possible facilitate the assimilation and naturalization of refugees. They shall in particular make every effort to expedite naturalization proceedings and to reduce as far as possible the charges and costs of such proceedings."

${ }^{11}$ HATHAWAY, James C.: The Rights of Refugees under International Law, Cambridge University Press, Cambridge 2005, p.156.

12 INELI-CIGER, p.38.

${ }^{13}$ DURIEUX, Jean-François: “Temporary Protection: Hovering at the Edges of Refugee Law", p.225.

${ }^{14}$ EGGLI, A Vibeke Eggli: Mass Refugee Influx and the Limits of Public International Law, Martinus Nijhoff Publishers, The Hague 2002, p.23.
} 
the possible indicators of "mass-influx situations" as large-scale and rapid arrival of displaced people, inadequacy of host state capacities and national asylum mechanisms in dealing with asylumseekers, and consideration of the situation as a threat to national security of the host state. ${ }^{15}$

Since "mass movement" is not mentioned within the Refugee Convention, debates on the place of mass movement by legal scholars consider the interpretation of the Refugee Convention provisions and their drafting history. The doctrinal studies could not agree upon the applicability on the Refugee Convention. Some scholars, such as Goodwin-Gill and McAdam, in their co-authored book, argue that the refugee definition of the Refugee Convention is "essentially individualistic", and at odds with the cases of mass movements. ${ }^{16}$ McAdam and Durieux, this time in their coauthored article, underscore that arguing that the Refugee Convention cannot be applied to largescale refugee movements is "tantamount to saying that the individual does not exist in a group". ${ }^{17}$ They refer to the discussions during the drafting process which were focused on "categories of refugees", implying that refugeehood does not only cover individuals. ${ }^{18}$ As an important reminder, the UNHCR Statute, which was adopted in 1950, expressly states that UNHCR's work "shall relate, as a rule, to groups and categories of refugees." 19 According to the UNHCR's interpretation, the problems of application of the Refugee Convention is related to the ways States apply the Convention rather than its provisions. ${ }^{20}$

As mentioned above, one of the indicators of the large-scale refugee movements is related to the difficulty of conducting RSDs during large-scale refugee movements in investigating each asylum claim on its own merits. In this regard, many refugee-hosting states in Africa and South America, and the UNHCR apply prima facie refugee status on a group basis without recourse to individual RSDs. ${ }^{21}$ While granting prima facie refugee status, determination process heavily relies on "objective and supplementary information". ${ }^{22}$ Crucially, "prima facie refugees obtain same rights as Convention refugees, at least in theory. ${ }^{23}$

Furthermore, reasons for persecution can be more complex than the restricted understanding of persecution given in the Refugee Convention. The scope of the definition of refugee privileges certain grounds of persecution and omits other potential reasons for forced displacement, such as socio-economic violence, wars, or indiscriminate violence that might also lead to displacement during large-scale refugee movements. In dealing with the shortcoming of the Refugee Convention, a more inclusive definition of refugee was adopted by the Organization of the African Union (OAU) in 1969 which includes "external aggression, occupation, foreign domination or events seriously disturbing public order" as basis of persecution. ${ }^{24}$ Similarly, the Cartagena Declaration of 1984 in South America includes "generalized violence, foreign aggression, internal conflicts, massive violation of human rights or other circumstances which have seriously disturbed public order." 25

Tuitt underlines that the Refugee Convention's international definition has survived such alternative claims to recognition of refugees. ${ }^{26}$ As we will discuss below, rather than adopting a more inclusive definition, the challenge of an alternative construction of refugees has been handled by international refugee law through the introduction of "quasi-legal statuses" ${ }^{27}$ such as temporary protection. In the dominant discourse, mass displacements have continued to be labelled as

\footnotetext{
${ }^{15}$ INELI-CIGER, p.36.

${ }^{16}$ GOODWIN-GILL, Guy S./MCADAM, Jane: The Refugee in International Law, 3rd edition, Oxford University Press, Oxford 2007, p.22.

${ }^{17}$ DURIEUX, Jean-François/MCADAM, Jane: "Non-Refoulement through Time: The Case for a Derogation Clause to the Refugee Convention in Mass Influx Emergencies”, International Journal of Refugee Law, 16(1), 2004, p.9.

${ }^{18}$ DURIEUX/MCADAM, p. 10.

${ }^{19}$ Statute of the Office of the United Nations High Commissioner for Refugees, (adopted 14.12.1950) UNGA Res $428(\mathrm{~V})$, para. 2

${ }^{20}$ UNHCR: "Note on International Protection", para.26-27. The same position reiterated in 2001: UNHCR: "Protection of Refugees in Mass Influx Situations: Overall Protection Framework", EC/GC/01/4, 2001, para.17.

${ }^{21}$ UNHCR: "Guidelines on International Protection No11: Prima Facie Recognition of Refugees", 2015.

${ }^{22}$ ALBERT, Matthew: "Governance and Prima Facie Refugee Status Determination: Clarifying the Boundaries of Temporary Protection, Group Determination, and Mass Influx. Refugee Survey Quarterly", 29(1), 2010, p.64.

${ }^{23}$ ALBERT, p.65.

${ }^{24}$ Organization of African Unity Convention Governing the Specific Aspects of Refugee Problems in Africa, 1001 UNTS 45, 10.09.1969, Article 1(2).

${ }^{25}$ Cartagena Declaration on Refugees, Colloquium on the International Protection of Refugees in Central America, Mexico and Panama, 22.11.1984, III(3).

${ }^{26}$ TUITT, Patricia: "Racist Authorization, Interpretive Law and the Changing Character of the Refugee" in Fitzpatrick, Peter (ed.), Nationalism, Racism and the Rule of Law, Aldershot, Darmouth 1995, p.51.

${ }^{27}$ TUITT: "Racist Authorization, Interpretive Law and the Changing Character of the Refugee", p.54.
} 
"crises"- exceptional situations that call for exceptional responses. ${ }^{28}$ Temporary protection emerged as such an exceptional response and has been formulated as a "pragmatic tool" ${ }^{29}$ to address gaps in the protection of refugees in situations of large-scale movements.

Crucially, the temporality of refugee identity has been rediscovered during the large-scale movements. The protection of refugees is inherently a temporary process - awaiting "finding permanent solutions to refugees' displacement", which is a task undertaken by the UNHCR. ${ }^{30}$ The traditional model of durable solutions aims at the "reattachment [of refugees] to a state" through repatriation to the country of origin, resettlement in a third country or, local integration/naturalization in the host country. ${ }^{31}$ However, under temporary protection, the durable solution of integration is dismissed and the conceptualization of temporary protection has been realized depending on the temporality of refugees in the immediate host countries until the realization of permanent solutions elsewhere. Hence, the development of temporary protection needs to be contextualized within the broader discussion of the durable solutions discourse, which is explored in the next section.

\section{FROM TEMPORARY REFUGE TO TEMPORARY PROTECTION}

When the contemporary international legal system of refugee protection was established following the Second World War, the Cold War politics was crucial in the international politics of refugee movements and durable solutions. Refugee relief during the Cold War years can be described as "part of an overall strategy to defeat or contain Communism". ${ }^{32}$ To this end, USA and European states were eager to grant refugee status to those who were escaping the Soviet regime to "reaffirm the failures of Communism". ${ }^{33}$ The expansion of economies in the Western states were also instrumental since refugees' labor force was welcomed following the loss of labor force in the Second World War. ${ }^{34}$ Although large-scale refugee movements put the refugee-protection regime to the test during the Cold War years, the prioritization of resettlement in the West as the preferred durable solution had a profound impact on the global management of large-scale refugee movements and the introduction of the concept of "temporary refuge".

The codification of temporary refuge in international documents was first realized in the context of the Indo-Chinese refugee movement during the late 1970s when over one million refugees from Cambodia, Laos and Vietnam sought asylum in Southeast Asian countries. ${ }^{35}$ Regional countries were not party to the Refugee Convention/Protocol, and they were reluctant to admit large numbers of displaced people. In 1979, when the industrialized states of the North agreed to conduct a large-scale and rapid resettlement, the regional states agreed to provide temporary asylum for refugees. ${ }^{36}$

The Cold War politics and consensus to resettle refugees outside of first asylum countries are important in understanding the initial conceptualization of "temporary refuge". Temporary refuge was framed as an "interim solution" ${ }^{37}$ linked to the durable solution of resettlement. Goodwin-Gill, who was involved in the development of temporary refuge as a staff member of the UNHCR, argues that temporary refuge aimed to establish a link between admission of refugees and burden-sharing among the states in the form of resettlement. ${ }^{38}$ In 1977, the UNHCR ExCom Conclusion No 5 appealed to first countries of asylum to grant "at least temporary asylum". ${ }^{39}$ In 1979, the Executive

\footnotetext{
${ }^{28}$ DAUVERGNE, Catherine: "Refugee Law as Perpetual Crisis" in Juss, Satvinder Singh/Harvey, Colin (ed.), Contemporary Issues in Refugee Law, Edward Elgar Publishing, Cheltenham 2013, p.19.

${ }^{29}$ UNHCR: "Guidelines on Temporary Protection or Stay Arrangements (TPSAs)", 2014, para.3.

${ }^{30}$ Statute of the Office of the United Nations High Commissioner for Refugees, para.1.

${ }^{31}$ EDWARDS, p.612.

${ }^{32}$ GOODWIN-GILL, Guy S: “The Refugee Identity and Protection's Fading Prospect”, in Nicholson, Frances/Twomey, Patrick (ed.), Refugee Rights and Realities: Evolving International Concepts and Regimes, Cambridge University Press, Cambridge 1999, p.223.

${ }^{33}$ LOESCHER, Gil: The UNHCR and World Politics: A Perilous Path, Oxford University Press, Oxford 2001, p.7.

${ }^{34}$ CHIMNI, BS: "From Resettlement to Involuntary Repatriation: Towards a Critical History of Durable Solutions to Refugee Problems", Refugee Survey Quarterly, 23(3), 2004, p.57.

${ }^{35}$ United Nations General Assembly: "Meeting on Refugees and Displaced Persons in South-East Asia", UN Doc A/34/627, 07.11.1979, para.1.

${ }^{36}$ United Nations General Assembly: "Meeting on Refugees and Displaced Persons in South-East Asia", para.15.

${ }^{37}$ CREPEAU, François/HOLLAND, Leanne: "Temporary Protection, Continuing Insecurity: A Regime Replacing Convention Protection of Refugees in Violations of International Law", Canadian Journal of Law and Society, 12(1), 1997, p.242.

${ }^{38}$ GOODWIN-GILL, Guy S: "Non-Refoulement, Temporary Refuge, and the "New” Asylum Seekers", p.433.

${ }^{39}$ UNHCR: "Executive Committee Conclusion No 5: Asylum", para.(d).
} 
Committee reiterated its call, and urged that "in cases of large-scale influx", states should always grant "at least temporary refuge". 40

The Group of Experts on Temporary Refuge met in 1981 and the ExCom Conclusion on "Protection of Asylum in Situations of Large-Scale Influx (No 22)" was adopted. It became a primary soft-law instrument, which constituted the key document in the development of temporary refuge, and later on temporary protection. ${ }^{41}$ Conclusion No 22 defined a broad category of people as potential beneficiaries of temporary refuge. In addition to refugees of the Refugee Convention, persons who seek refuge "owing to external aggression, occupation, foreign domination or events seriously disturbing public order" were to benefit from the temporary refuge. ${ }^{42}$ As for the measures of protection, Conclusion No 22 underlined admission to states "at least on a temporary basis" 43 , protection against refoulement ${ }^{44}$, and treatment of beneficiaries according to "minimum basic human rights". ${ }^{45}$

Nevertheless, beyond admission and non-refoulement, the standards of protection remained ambiguous. In this regard, Hartman and Perluss pointed out in 1986 that temporary refuge acquires a customary law status, but its content beyond the ban on forcible return has "yet to be critically examined" ${ }^{46}$ Conclusion No 22 refrained from explicit references to the rights, and instead referred to the "minimum basic human standards" that should be observed. The minimum standards included exemption from penalty for unlawful presence in the country, fundamental civil rights, basic necessities of life - including food, shelter, basic sanitary and health facilities, not being subject to cruel, inhuman or degrading treatment, not being discriminated against, free access to courts, and respect for the family unit. ${ }^{47}$ Significantly, they did not refer to some fundamental rights such as the right to identity documents, the right to education or the right to work.

Although the concept of temporary refuge has been developed in a particular historical context, it constituted the basis of the development of temporary protection in the 1990s, albeit in a "new and distinct phase". ${ }^{48}$ The 1990s witnessed a shift in preferred durable solutions from resettlement to repatriation. Beginning in the 1980s, resettlement as a response to refugee movements had already been questioned by the Global North in situations other than the Cold War context. ${ }^{49}$ More and more refugees from the global South were migrating to the global North, and there was no more need for labor force in the global North that would facilitate acceptance of refugees. ${ }^{50}$

In the context of the 1990s as the "decade of repatriation", ${ }^{51}$ the concept of temporary refuge has been transformed into temporary protection. Temporary protection was heavily discussed with regard to the displacement of Bosnian refugees from ex-Yugoslavia to European states in the early 1990s. When the Bosnian refugees were seeking protection in European states, which have been party to the Refugee Convention/Protocol, European states were reluctant to admit increasing number of Bosnians. As a political compromise, in 1992, the then United Nations High Commissioner for Refugees Sadako Ogata urged States to provide temporary protection that would "encourage eventual return as the most desirable and feasible solution [emphasis added]." " The

${ }^{40}$ UNHCR: "Executive Committee Conclusion No 15: Refugees Without an Asylum Country", para.(f).

${ }^{41}$ UNHCR: "Executive Committee Conclusion 22: Protection of Asylum-Seekers in Situations of Large-Scale Influx", 1981.

${ }^{42}$ UNHCR: "Executive Committee Conclusion 22: Protection of Asylum-Seekers in Situations of Large-Scale Influx", Section.I para.(1).

${ }^{43}$ UNHCR: "Executive Committee Conclusion 22: Protection of Asylum-Seekers in Situations of Large-Scale Influx", Section.II(A) para.(1).

${ }^{44}$ UNHCR: "Executive Committee Conclusion 22: Protection of Asylum-Seekers in Situations of Large-Scale Influx", para.2.

${ }^{45}$ UNHCR: "Executive Committee Conclusion 22: Protection of Asylum-Seekers in Situations of Large-Scale Influx", para.2.

${ }^{46}$ HARTMAN/PERLUSS, p.555.

${ }^{47}$ UNHCR: "Executive Committee Conclusion 22: Protection of Asylum-Seekers in Situations of Large-Scale Influx", Section II(B) para.2.

${ }^{48}$ GIBNEY, p.693.

${ }^{49}$ CHIMNI, p.58.

${ }^{50}$ CHIMNI, p.58.

${ }^{51}$ UNHCR: "Statement by Mrs. Sadako Ogata, United Nations High Commissioner for Refugees, at the International Management Symposium, St. Gallen, Switzerland”, 25.05.1992, https://www.unhcr.org/uk/admin/hcspeeches/3ae68faec/statement-mrs-sadako-ogata-united-nations-highcommissioner-refugees-international.html, (Accessed: 09.08.2021).

${ }^{52}$ UNHCR: "Report of the International Meeting on Humanitarian Aid to Victims of the Conflict in the Former Yugoslavia”, HCR/IMFY/1992/4, 10.08.1992, para.13. 
UNHCR's proposal for temporary protection included four elements: "admission to the country... respect for the principle of non-refoulement and basic human rights (outlined in the Conclusion No 22 ), and repatriation when conditions so allow in the country of origin." ${ }^{53}$ In response, several European states provided temporary protection for over 500,000 Bosnians. ${ }^{54}$ The practice of temporary protection in Europe differed from one state to another, yet the standards were in line with the UNHCR proposal and the protection was granted on a groups basis, with the expectation of repatriation of its beneficiaries to their countries of origin in a short period of time. ${ }^{55}$ In this respect, unlike the Indo-Chinese refugee case, temporary protection in Europe was not an intermediate step pending resettlement as a durable solution, but absolutely contingent upon the possibility of their eventual return. ${ }^{56}$

Building upon European practice, the discussions in policy circles have attempted to standardize/improve the conceptualization of temporary protection. According to the UNHCR's 1994 International Note on Protection, the focus on return provides the rationale for efforts to minimize integration. ${ }^{57}$ However, since there is no time limitation for the duration of temporary protection ${ }^{58}$ both Convention refugees and other displaced people who need protection might remain under temporary protection for a prolonged or indefinite period of time. The need for a progressive improvement of standards in the case of a prolonged stay is suggested; yet the actual levels of treatment are agreed to be in line with the reception capacity of the receiving state ${ }^{59}$ In 2001, when protection of refugees in "mass influx situations" was discussed as part of the Global Consultations on International Protection, temporary protection is reconsidered as "a practical device". ${ }^{60}$ Once more, the need for the improvement of standards in the case of prolonged stay and the potential value of harmonized approach to standards of treatment are highlighted, without providing parameters. ${ }^{61}$

During the period of harmonization of the asylum system in the EU, temporary protection was formalized on a regional level with the adoption of the EU Council Directive on Temporary Protection in $2001 .^{62}$ The concept is adopted as a "procedure of exceptional character" in the events of a "mass influx" ${ }^{63}$. In the Council Directive, the standards of treatment include the right to education, the right to work $^{64}$, the right to housing, the right to social welfare, and family reunification. ${ }^{65}$ Furthermore, the Directive standardized the duration of temporary protection as one year, which can be prolonged to up to three years. ${ }^{66}$ Access to an asylum procedure was secured with the requirement that the processing of asylum applications shall be completed after the termination of the temporary protection ${ }^{67}$ However, the Council Directive introduced a complicated procedure for the activation of temporary protection, which requires a decision adopted by a qualified majority ${ }^{68}$ Since its entry into force, the activation of the Directive became a concern during Afghani, Iraqi, North African, and Syrian refugee movements, but, under the Directive, European states have yet to reach a consensus on implementing temporary protection. ${ }^{69}$

\footnotetext{
${ }^{53}$ UNHCR: "Report of the International Meeting on Humanitarian Aid to Victims of the Conflict in the Former Yugoslavia", para.13.

${ }^{54}$ UNHCR: "The State of World Refugees", 1997, figure 5.6.

${ }^{55}$ KOSER, Khalid/BLACK, Richard: "Limits to Harmonization: The 'Temporary Protection' Refugees in the European Union”, International Migration, 37(3), 1999, p.527.

${ }^{56}$ KJAERUM, p.449.

${ }^{57}$ UNHCR: "Note on International Protection", para.50.

${ }^{58}$ UNHCR: "Note on International Protection", para.50.

${ }^{59}$ UNHCR: "Note on International Protection", para. 49.

${ }^{60}$ UNHCR: "Protection of Refugees in Mass Influx Situations: Overall Protection Framework", para.13.

${ }^{61}$ UNHCR: "Protection of Refugees in Mass Influx Situations: Overall Protection Framework", para.15.

${ }^{62}$ Council of the European Union: Council Directive on Minimum Standards for Giving Temporary Protection in the Event of a Mass Influx of Displaced Persons and on Measures Promoting a Balance of Efforts Between Member States in Receiving such Persons and Bearing the Consequences Thereof, OJL.212/12-212/23, 2001/55/EC, 07.08.2001.

${ }^{63}$ Council of the European Union, Article 2(a).

${ }^{64}$ A limitation on right to work is put as: "For reasons of labour market policies, Member States may give priority to EU citizens and citizens of States bound by the Agreement on the European Economic Area and also to legally resident third- country nationals who receive unemployment benefit": Council of the European Union, Article 12.

${ }^{65}$ Council of the European Union, Chapter III.

${ }^{66}$ Council of the European Union, Article 4.

${ }^{67}$ Council of the European Union, Article 17.

${ }^{68}$ Council of the European Union, Article 5.

${ }^{69}$ NASCIMBENE, Bruno/PASCALE, Alessia Di: "The "Arab Spring" and the Extraordinary Influx of People who Arrived in North Italy from North Africa", European Journal of Migration and Law, 13(4), 2011, p.346; AKRAM, Susan M. (et.al): "Protecting Syrian Refugees: Laws, Policies, and Global Responsibility Sharing", Boston University School of Law International Human Rights Clinic, 2014. http://www.bu.edu/law/files/2015/07/FINALFullReport.pdf,
} 
The UNHCR continued to call for the implementation of temporary protection in the $21^{\text {st }}$ century. The large-scale Syrian displacement, beginning in 2011, triggered the latest discussions on the effectiveness of the international refugee regime. The discussions on the concept of temporary protection have been revitalized as the neighboring countries of Jordan, Lebanon, and Turkey host the overwhelming majority of Syrians on a temporary basis. ${ }^{70}$ Once more, the UNHCR published Guidelines on Temporary Protection or Stay Arrangements (TPSAs) to support states in addressing large-scale refugee movements and humanitarian crises. ${ }^{71}$ The Guidelines attempted to improve the standards of temporary protection, ${ }^{72}$ however, they did not determine the duration of temporary protection and advised it to be extended as conditions persist. ${ }^{73}$ Hence, it is derived from the Guidelines that temporary protection might continue indefinitely, depending on the root causes of the displacement. ${ }^{74}$

As discussed above, the relationship between durable solutions had a profound impact on the emergence and the development of temporary protection frameworks. The shift in preferred durable solutions from resettlement to repatriation mirrored in the transformation from temporary refuge to temporary protection. ${ }^{75}$ Since the durable solutions are aspired to be found outside of the host countries, and integration to host country is not considered, the content of temporary protection remained ambiguous. Beyond admission to state territories and protection against refoulement, the legal status of temporary protection beneficiaries and their rights under temporary protection have not been clarified. In this sense, temporary protection involves 'putting brakes on the 'integration machine" ${ }^{76}$ in the host country for an indefinite period of time and its success solely depends on the realization of durable solutions elsewhere. In other words, the temporary protection turns into permanent-temporary protection in the context of the failure of durable solutions.

\section{FAILURE OF DURABLE SOLUTIONS AND UNCERTAINTIES}

As discussed above, there is a close relationship between the traditional durable solutions frameworks and the development of temporary protection regimes. This section further explores the inherent uncertainties of temporary protection regimes, which are intrinsically related to the failure of durable solutions in the contemporary international refugee regime. The current situation of refugees reveals the failure of the discourse on traditional durable solutions. The UNHCR Global Trends gives a snapshot of forced migration world-wide on a yearly basis. Although the statistics are not reliable for understanding forced migration qualitatively, and numbers are silent on experiences of forced migrants and their struggles or strategies, they are strong indicators of the failure of the current refugee regime in bringing a "solution" to displacement. According to the latest UNHCR Global Trends of 2020, 82.4 million people were forcibly displaced from their homes as a result of persecution, conflict, or generalized violence, including 48 million internally displaced people. ${ }^{77}$ Among refugees, 15.7 million people - which represents 76 per cent of the total number of refugees - are in protracted refugee situations, which according to the UNHCR definition means that they have been displaced for more than five years. ${ }^{78}$ Contrary to the discourse of durable solutions, it is a well-established fact that protracted displacement has become the norm in forced migration. ${ }^{79}$

Temporary protection creates and maintains uncertainty as a refugee management strategy within the failure of the international refugee regime and its traditional durable solutions framework. As Horst and Grabska underline, "radical uncertainty" is inherent to people's experiences during the initial stages of conflict-induced displacement. As they explain, the sources of radical uncertainty are the imperfect knowledge about one's environment, and the unpredictability of the

(Accessed: 04.08.2021); ORCHARD, Cynthia/MILLER, Andrew: "Protection in Europe for Refugees from Syria". Oxford Refugee Studies Centre, 2014.

70 "Regional Refugee and Resilience Plan: Regional Strategic Overview 2019-2020", 2019.

${ }^{71}$ UNHCR: "Guidelines on Temporary Protection or Stay Arrangements (TPSAs)", para.4.

${ }^{72}$ UNHCR: "Guidelines on Temporary Protection or Stay Arrangements (TPSAs)", para.16.

${ }^{73}$ UNHCR: "Guidelines on Temporary Protection or Stay Arrangements (TPSAs)", para.20.

${ }^{74}$ KAGAN, Michael: "UNHCR Issues New Guidelines on Temporary Protection", 2014, https://rsdwatch.com/2014/03/20/unhcr-issues-new-guidelines-on-temporary-protection-they-need-a-rewrite/, (Accessed: 05.08.2021).

${ }^{75}$ ŞENGÜL, İrem: “Geçici Koruma Rejimleri ve Kalıcılığa Geçiş”, Göç Araştırmaları Vakfı Çalışma Raporu, 2021, p.7.

${ }^{76}$ DURIEUX: “Temporary Protection: Hovering at the Edges of Refugee Law”, p.236.

${ }^{77}$ UNHCR: "Global Trends", 2020, p.2.

${ }^{78}$ UNHCR: "Global Trends", 2020, p.20.

79 ZETTER, Roger: "Unlocking the Protracted Displacement of Refugees and Internally Displaced Persons: An Overview”, Refugee Survey Quarterly, 30(4), 2011, p.1. 
future ${ }^{80}$ An extreme sense of unpredictability is also related to the speed at which dramatic lifethreatening events happen, and a person's lack of control over their life choices. ${ }^{81}$ However, temporary protection leads to "protracted uncertainty", as a result of a combination of the neverending temporality of their stay in the country of refuge, uncertainties about the future, insecure legal statuses, and imperfect knowledge about one's conditions within the country of refuge. ${ }^{82}$

The protracted uncertainty inherent to the temporary protection frameworks is first constructed upon a tempo-spatial uncertainty. The temporary protection is conditioned upon the realization of a durable solution elsewhere other than the place of exile - through either repatriation or resettlement after an indefinite period of time. In other words, temporary protection provides two options for its beneficiaries in rebuilding their lives: either returning to their countries of origin or resettling in third countries. In either case, their future lies somewhere else. Without "knowing what comes next" ${ }^{93}$, and/or when it will happen, refugees struggle to make life choices, imagine a future, and invest in any future plans. Importantly, the durable solutions themselves might not indicate certainty or stability for refugees. That is, the shift from temporary protection to repatriation or resettlement as forms of "permanent solutions" do not necessarily bring an immediate end to the uncertainty of protracted exile.

Čapo, in her empirical study with former Croatian and Bosnian refugees who were repatriated or locally integrated, reveals that returnees could not simply rebuild their lives, since "they came back to what are radically transformed surroundings", while locally integrated refugees continued to struggle with belonging to a new environment. Both returnees and integrated refugees continued to experience the condition of being "immigrants", rather than a "naturalized returnee" or "settler". 84 Similarly, Hyndman and Giles' research on resettled refugees in Canada challenges the presumption that resettlement can be an easy solution for protection problems. They carefully underline that, although some refugees make use of resettlement as a strategy to have access to qualified protection, refugees might also face insecurity and uncertainty in their resettlement places. ${ }^{85}$ This is not to say that refugees do not consider repatriation or resettlement as a viable strategy to re-establish their lives. However, what is important from a refugee perspective is the continuity of the potential insecurities and uncertainties in thinking about available durable solutions. In other words, in contrast to the understanding of durable solutions as an immediate end to the problems of protection, refugees engage with potential post-durable solution uncertainties in their attempts to plan a future.

The legal status of temporary protection beneficiaries during their stay in host counties is also ambiguous, leading to further uncertainty. The legal status of a person in any given country defines her rights, obligations, freedoms, and also, restrictions. As Griffith argues, who is inside and who is outside of the law is crucial to perceiving the frontiers of legality. ${ }^{86}$ Dauvergne neatly explains how labelling people as "illegal" serves for their exclusion. According to her, when states cannot exclude foreigners by closing its borders, they separate the "nation" from the "others" through the labelling of illegality. The ones who are labelled as "illegals" are excluded and kept outside the law. ${ }^{87}$ At the same time, how people are included in law is of equal significance. As Zetter argues how one is labelled legally defines her subjectivity. ${ }^{88}$ Simply put, those who contravene the migration and refugee law would have an illegal status in a given country. ${ }^{89}$ Illegality is commonly used to refer to those who cross state borders by breaching the law, who overstay their permission to legally stay, those whose asylum application is rejected, and those whom (despite their intention) have not yet applied for asylum. ${ }^{90}$

\footnotetext{
${ }^{80}$ HORST, Cindy/GRABSKA, Katarzyna: "Introduction: Flight and Exile-Uncertainty in the Context of ConflictInduced Displacement", Social Analysis, 59(1), 2015, p.4-5.

${ }^{81}$ HORST/GRABSKA, p.5.

${ }^{82}$ HORST/GRABSKA, p.6.

${ }^{83}$ HYNDMAN, Jennifer/GILES, Wenona: Refugees in Extended Exile: Living on the Edge, Routledge, London 2017, p.xiv.

${ }^{84}$ CAPO, Jasna: ““'Durable Solutions”, Transnationalism, and Homemaking Among Croatian and Bosnian Former Refugees", Refuge, 31(1), 2015, p.24.

${ }^{85}$ HYNDMAN/GILES, p.115.

${ }^{86}$ GRIFFITHS, Anne: "Using Ethnography as a Tool in Legal Research: An Anthropological Perspective" in Banakar, Reza/Travers, Max (ed.), Theory and Method in Socio-Legal Research, Hart Publishing, Oxford 2005, p.114.

${ }^{87}$ DAUVERGNE, Catherine: Making People Illegal: What Globalization Means for Migration and Law, Cambridge University Press, Cambridge 2012, p.17-18.

${ }^{88}$ ZETTER, Roger: "Labelling Refugees: Forming and Transforming a Bureaucratic Identity", Journal of Refugee Studies, 4(1), 1991, p.39.

${ }^{89}$ DAUVERGNE: Making People Illegal: What Globalization Means for Migration and Law, p.11.

${ }^{90}$ DAUVERGNE: Making People Illegal: What Globalization Means for Migration and Law, p.11.
} 
In this sense, temporary protection status is not seen as an "illegal" status-and yet, it is undoubtedly not a secure status. The legal status of beneficiaries of temporary protection are designed on an ad hoc basis in different countries in the absence of an internationally accepted definition. Furthermore, host states might discretionally terminate the temporary protection. Contrary to the Refugee Convention and most domestic legislations which include detailed cessation clauses for the termination of refugee status, when and how temporary protection may cease remains uncertain in soft-law instruments on temporary protection. ${ }^{91}$ Upon the decision of the host state that voluntary return is reasonable, the beneficiaries of temporary protection can easily slip into illegality, if they overstay their legal permission to remain in the country.

Where resettlement, repatriation and local integration fail, temporary protection frameworks become pragmatic tools of states in keeping refugees under "permanent temporariness" 92 awaiting return. Hence, protracted uncertainty is inherently related to the failure of the durable solutions framework in bringing an end to the predicament of refugees - yet, it can also be considered as a "deliberate governance strategy" to avoid the settlement of its beneficiaries in places of refuge. ${ }^{93}$ Former UN High Commissioner for Refugees, Sadako Ogata, suggested the temporary protection in Europe as "a flexible system". ${ }^{94}$ It is now recognized that what she refers to as "flexibility" translates into insecurity and uncertainty with regard to the legality of temporary protection status. The non-activation of the Council Directive on Temporary Protection suggests that whenever temporary protection loses its "flexibility", state actors are disinclined to implement formalized temporary protection frameworks.

The discretionary power of authorities in delimiting the rights and freedoms of those temporarily protected has been discussed in previous sections. It is revealed that during the conceptualization of temporary protection, several related assumptions are made to justify the restrictions of the rights, freedoms, and security of the temporarily protected: (i) host state capacities are overwhelmed during large-scale movements of refugees; (ii) it is an interim solution and emergency response awaiting durable solutions; (iii) the focus on repatriation leads to efforts of minimizing integration. Although the UNHCR calls for improvements on standards of temporary protection with the passage of time, ${ }^{95}$ in practice this leads to a logical fallacy. How, when, or why host states would have capacity or wish to improve standards of protection is not clear. From a refugee perspective, uncertainty about access to certain rights, such as the right to work, or access to livelihoods - if at all-leads to great insecurity and precarity. Within the condition of protracted uncertainty, short-term uncertainty in regard to the insecurities of temporary protection status and rights of beneficiaries, and the long-term uncertainty related to the future of refugees intermingle. ${ }^{96}$

The discourse of temporary protection has a disturbing relationship with the broader restrictive policies of refugee protection. According to the UNHCR statistics, 86 per cent of refugees are living in the global South. ${ }^{97}$ While restrictive asylum policies and measures of control in the North already create "engineered regionalism", and contain refugees within their own countries or regions, ${ }^{98}$ regional temporary protection frameworks obviously run the risk of being another measure of control for Northern states. In this context, the pragmatic frameworks of temporary protection discussed above establish a top-down approach to refugee protection that focuses on state interests. They all have a fundamental aim: negotiating with states in order to convince them to implement at least temporary protection, since durable solutions are in crisis.

\footnotetext{
${ }^{91}$ Refugee Convention, Article 1(C); OAU Convention, Article I(4).

${ }^{92}$ BRUN, Cathrine/FABOS, Anita: "Making Homes in Limbo? A Conceptual Framework", Refuge, 31(1), 2015, p.6.

${ }^{93}$ BRUN/FABOS, p.6; BIEHL, Kristen S.: "Governing Through Uncertainty: Experiences of Being a Refugee in Turkey as a Country for Temporary Asylum", Social Analysis, 59(1), 2015, p.57.

94 "Statement of Mrs Sadako Ogata, United Nations High Commissioner for Refugees, to the International Meeting on Humanitarian Aid for Victims of the Conflict in the former Yugoslavia", 29.07.1992, https://www.unhcr.org/admin/hcspeeches/3ae68fac1a/statement-mrs-sadako-ogata-united-nations-high-commissionerrefugees-international.html, (Accessed: 02.08.2021).

${ }^{95}$ UNHCR: "The Note on International Protection", para.49.

${ }^{96}$ HORST/GRABSKA, p.8.

${ }^{97}$ UNHCR: "Global Trends", 2020, p.2.

${ }^{98}$ GIBNEY, Matthew J.: "Forced Migration, Engineered Regionalism, and Justice Between States" in Kneebone, Susan/Rawlings-Sanaei, Felicity (ed.), New Regionalism and Asylum Seekers, Berghahn Books, New York 2007, p.6263.
} 


\section{CONCLUSION}

Temporary protection has been discussed and reframed in policy and academic circles several times, as a pragmatic tool of addressing large-scale displacements. In this sense, the development of temporary protection at the international level can be directly linked to the failure of the international refugee regime in providing protection to refugees during large-scale displacements. This failure has been framed as "gaps in international protection" in the soft-law instruments and policy documents on temporary protection, particularly in the UNHCR ExCom Conclusions, Notes and Guidelines. Temporary protection, then, has been formulated to address these "gaps" by securing admission and protection against refoulement for a broader range of beneficiaries, including Convention refugees and non-Convention refugees, both in states party to the Refugee Convention/Protocol and in non-signatory states. However, beyond the facilitation of admission of people into state territories and protection against refoulement, the meaning or content of temporary protection has not been clarified.

In light of discussions on the failure of the international refugee regime during large-scale movements, the failure to define the meaning of temporary protection is not a coincidence. On the contrary, it is the "flexible" and discretionary nature of the temporary protection framework that makes it a "pragmatic" response in convincing states to admit refugees, and in managing the refugee movements through the uncertainties of temporary protection status. In this sense, the calls for standardizing temporary protection could not have an effect in further reconsiderations of temporary protection at the international level. The hallmark of temporary protection that appeals to state interests in various regions is its inherent ambiguity and uncertainty-functioning as a refugeemanagement and governance strategy. Hence, the failure of defining the meaning, content, and scope of temporary protection in various soft-law instruments should not be understood to be a coincidence. In this sense, the non-activation of the EU Council Directive on Temporary Protection - which is the only successful attempt so far to formalize temporary protection at a regional level—supports the argument that temporary protection loses its allure for states when it is standardized.

Temporary protection has been constructed upon the eventual return of refugees, within the broader context of the transformation of preferred durable solutions in international refugee regime since the late 1980s/early 1990s. The presumed function of temporary protection in facilitating the eventual return of refugees legitimizes refugee containment within the region of origin and reinforces their immobility. Considering that the overwhelming majority of refugees are already living in the host countries of the Global South, the close links between temporality, containment, and return justify the Global North's restrictive admission policies in preventing the arrival of refugees at their borders. Equally important, in such a formulation, resettlement becomes "unnecessary" since refugees are kept within the host countries of the Global South for an indefinite period of time. The top-down frameworks of temporary protection are constructed as problemsolving approaches, working within the paradigm of durable solutions. Where and when the traditional durable solutions to place large numbers of displaced people into the nation-state system fails, temporary protection is considered a "practical" response to fill the gaps - that is, practical for the states.

\section{BIBLIOGRAPHY}

ALBERT, Matthew: "Governance and Prima Facie Refugee Status Determination: Clarifying the Boundaries of Temporary Protection, Group Determination, and Mass Influx", Refugee Survey Quarterly, 29(1), 2010.

AKRAM, Susan M. (et.al): "Protecting Syrian Refugees: Laws, Policies, and Global Responsibility Sharing", Boston University School of Law International Human Rights Clinic, 2014. http://www.bu.edu/law/files/2015/07/FINALFullReport.pdf, (Accessed: 04.08.2021).

BIEHL, Kristen S.: "Governing Through Uncertainty: Experiences of Being a Refugee in Turkey as a Country for Temporary Asylum", Social Analysis, 59(1), 2015.

BRUN, Cathrine/FABOS, Anita: "Making Homes in Limbo? A Conceptual Framework", Refuge, 31(1), 2015.

CAPO, Jasna: “'”Durable Solutions”, Transnationalism, and Homemaking Among Croatian and Bosnian Former Refugees", Refuge, 31(1), 2015.

Cartagena Declaration on Refugees, Colloquium on the International Protection of Refugees in Central America, Mexico and Panama, 22.11.1984. 
CHIMNI, BS: "From Resettlement to Involuntary Repatriation: Towards a Critical History of Durable Solutions to Refugee Problems", Refugee Survey Quarterly, 23(3), 2004.

COLES, G.J.L.: "Temporary Refuge and the Large Scale Influx of Refugees", Australian Year Book of International Law, 8, 1978-1980.

Convention Relating to the Status of Refugees (adopted 28.07.1951, entered into force 22.04.1954) 189 UNTS 137

Council of the European Union: Council Directive on Minimum Standards for Giving Temporary Protection in the Event of a Mass Influx of Displaced Persons and on Measures Promoting a Balance of Efforts Between Member States in Receiving such Persons and Bearing the Consequences Thereof, OJL.212/12-212/23, 2001/55/EC, 07.08.2001.

CREPEAU, François/HOLLAND, Leanne: "Temporary Protection, Continuing Insecurity: A Regime Replacing Convention Protection of Refugees in Violations of International Law", Canadian Journal of Law and Society, 12(1), 1997.

DAUVERGNE, Catherine: Making People Illegal: What Globalization Means for Migration and Law, Cambridge University Press, Cambridge 2012.

DAUVERGNE, Catherine: Refugee Law as Perpetual Crisis, in Juss, Satvinder Singh/Harvey, Colin (ed.), Contemporary Issues in Refugee Law, Edward Elgar Publishing, Cheltenham 2013.

DURIEUX, Jean-François: "Temporary Protection: Hovering at the Edges of Refugee Law" in Ambrus, Monika/Wessel, Ramses A. (ed.), Netherlands Yearbook of International Law 2014: Between Pragmatism and Predictability: Temporariness in International Law, Asser Press, The Hague 2015.

DURIEUX, Jean-François/MCADAM, Jane: "Non-Refoulement through Time: The Case for a Derogation Clause to the Refugee Convention in Mass Influx Emergencies", International Journal of Refugee Law, 16(1), 2004.

EDWARDS, Alice: “Temporary Protection, Derogation and the 1951 Refugee Convention”, Melbourne Journal of International Law, 13(2), 2012.

EGGLI, A Vibeke Eggli: Mass Refugee Influx and the Limits of Public International Law, Martinus Nijhoff Publishers, The Hague 2002.

FERRIS, Elizabeth G.: The Politics of Protection: The Limits of Humanitarian Action, Brookings Institution Press, Washington, D.C. 2011.

FITZPATRICK, Joan: "Revitalizing the 1951 Refugee Convention”, Harvard Human Rights Journal, 9, 1996.

FITZPATRICK, Joan: "Temporary Protection of Refugees: Elements of a Formalized Regime", American Journal of International Law, 94(2), 2000.

GIBNEY, Matthew J.: "Between Control and Humanitarianism: Temporary Protection in Contemporary Europe", Georgetown Immigration Law Journal, 14(3), 2000.

GIBNEY, Matthew J.: "Forced Migration, Engineered Regionalism, and Justice Between States" in Kneebone, Susan/Rawlings-Sanaei Felicity (ed.), New Regionalism and Asylum Seekers, Berghahn Books, New York 2007.

GOODWIN-GILL, Guy S: "The Refugee Identity and Protection's Fading Prospect" in Nicholson, Frances/Twomey, Patrick (ed.), Refugee Rights and Realities: Evolving International Concepts and Regimes, Cambridge University Press, Cambridge 1999.

GOODWIN-GILL, Guy S./MCADAM, Jane: The Refugee in International Law, 3rd edition, Oxford University Press Oxford, 2007.

GRIFFITHS, Anne: "Using Ethnography as a Tool in Legal Research: An Anthropological Perspective" in Banakar, Reza/Travers, Max (ed.), Theory and Method in Socio-Legal Research, Hart Publishing, Oxford 2005.

HARTMAN, Joan F./PERLUSS, Deborah: “Temporary Refuge: Emergence of a Customary Law”, Virginia Journal of International Law, 26(3), 1986.

HATHAWAY, James C./NEVE R. Alexander: "Making International Refugee Law Relevant Again: A Proposal for Collectivized and Solution-Oriented Protection", Harvard Human Rights Journal, 10, 1997.

HATHAWAY, James C.: The Rights of Refugees under International Law, Cambridge University Press, Cambridge 2005.

HORST, Cindy/GRABSKA, Katarzyna: "Introduction: Flight and Exile-Uncertainty in the Context of Conflict-Induced Displacement", Social Analysis, 59(1), 2015.

HYNDMAN, Jennifer/GILES, Wenona: Refugees in Extended Exile: Living on the Edge, Routledge, London 2017.

KAGAN, Michael: "UNHCR Issues New Guidelines on Temporary Protection”, 2014, https://rsdwatch.com/2014/03/20/unhcr-issues-new-guidelines-on-temporaryprotection-they-need-a-rewrite/, (Accessed: 05.08.2021).

KJAERUM, Morten: "Opinion: Temporary Protection in Europe in the 1990s", International Journal of Refugee Law, 6(3), 1994.

KOSER, Khalid/BLACK, Richard: "Limits to Harmonization: The 'Temporary Protection' Refugees in the European Union”, International Migration, 37(3), 1999. 
LOESCHER, Gil: The UNHCR and World Politics: A Perilous Path, Oxford University Press, Oxford 2001. NASCIMBENE, Bruno/PASCALE, Alessia Di: "The 'Arab Spring' and the Extraordinary Influx of People who Arrived in North Italy from North Africa”, European Journal of Migration and Law, 13(4), 2011.

ORCHARD, Cynthia/MILLER, Andrew: "Protection in Europe for Refugees from Syria", Oxford Refugee Studies Centre, 2014.

Organization of African Unity Convention Governing the Specific Aspects of Refugee Problems in Africa, 1001 UNTS 45, 10.09.1969.

"Regional Refugee and Resilience Plan: Regional Strategic Overview 2019-2020", 2019.

"Statement of Mrs Sadako Ogata, United Nations High Commissioner for Refugees, to the International Meeting on Humanitarian Aid for Victims of the Conflict in the former Yugoslavia", 29.07.1992, https://www.unhcr.org/admin/hcspeeches/3ae68fac1a/statement-mrssadako-ogata-united-nations-high-commissioner-refugees-international.html, (Accessed: 02.08.2021).

Statute of the Office of the United Nations High Commissioner for Refugees, (adopted 14.12.1950), UNGA Res 428(V).

STEVENS, Dallal: “What Do We Mean by Protection?”, International Journal of Minority and Group Rights, 20(1), 2013.

ŞENGÜL, İrem: “Geçici Koruma Rejimleri ve Kalıcılığa Geçiş”. Göç Araştırmaları Vakfı Çalışma Raporu, 2021.

TUITT, Patricia: False Images: The Law's Construction of the Refugee, Pluto Press, London 1996.

TUITT, Patricia: "Racist Authorization, Interpretive Law and the Changing Character of the Refugee" in Fitzpatrick, Peter (ed.), Nationalism, Racism and the Rule of Law, Aldershot, Darmouth 1995.

UNHCR: "Executive Committee Conclusion No 5: Asylum", 1977.

UNHCR: "Executive Committee Conclusion No 15: Refugees Without an Asylum Country", 1979.

UNHCR: "Executive Committee Conclusion 22: Protection of Asylum-Seekers in Situations of Large-Scale Influx", 1981.

UNHCR: "Statement by Mrs. Sadako Ogata, United Nations High Commissioner for Refugees, at the International Management Symposium, St. Gallen, Switzerland”, 25.05.1992, https://www.unhcr.org/uk/admin/hcspeeches/3ae68faec/statement-mrs-sadako-ogataunited-nations-high-commissioner-refugees-international.html, (Accessed: 09.08.2021).

UNHCR: "Report of the International Meeting on Humanitarian Aid to Victims of the Conflict in the Former Yugoslavia”, HCR/IMFY/1992/4, 10.08.1992.

UNHCR: "The State of World Refugees", 1993.

UNHCR: "Note on International Protection", UN Doc A/AC.96/830, 1994.

UNHCR: "The State of World Refugees", 1997.

UNHCR: "Protection of Refugees in Mass Influx Situations: Overall Protection Framework", EC/GC/01/4, 2001.

UNHCR: "Executive Committee Conclusion No 100: International Cooperation and Burden and Responsibility Sharing in Mass Influx Situations", 2004.

UNHCR: "Roundtable on Temporary Protection: Summary Conclusions on Temporary Protection", 2012.

UNHCR: "Guidelines on Temporary Protection or Stay Arrangements (TPSAs)", 2014.

UNHCR: "Guidelines on International Protection No11: Prima Facie Recognition of Refugees", 2015.

United Nations General Assembly: "Meeting on Refugees and Displaced Persons in South-East Asia". UN Doc A/34/627, 07.11.1979.

ZETTER, Roger: "Labelling Refugees: Forming and Transforming a Bureaucratic Identity", Journal of Refugee Studies, 4(1), 1991.

ZETTER, Roger: "Unlocking the Protracted Displacement of Refugees and Internally Displaced Persons: An Overview”, Refugee Survey Quarterly, 30(4), 2011. 